\title{
Determinants of occurrence of excessive optimism among analysts of the Warsaw Stock Exchange*
}

\author{
Radosław Pastusiak ${ }^{1}$ Jakub Keller ${ }^{2}$
}

\begin{abstract}
This paper deals with the phenomenon of excessive optimism in brokerage valuations, which is manifested by one-sided errors in the valuation of securities in reference to the real price achieved by the particular stock in the horizon of one year. The phenomenon of over-optimism is complex both from the perspective of the individual characteristics of stock market analysts as well as the psychological aspects of market functioning and the mechanisms that determine the volatility of stock prices. Due to the wide range of factors affecting the occurrence of the examined phenomenon, the authors focus only on the market aspects influencing the occurrence of excessive optimism in brokerage recommendations. The research examines over 10,000 recommendations for companies from the Warsaw Stock Exchange and from more than 40 financial institutions which evaluated companies in the period 2000-2014. For the purposes of analyzes, over-optimism in valuations is defined as an overestimation of the target price in the case of positive recommendations and as an underestimation of the price decline in the case of negative ones. The results confirmed the hypotheses of the heterogeneity of the phenomenon of excessive optimism both for different economic sectors and individual financial institutions. The authors see it as a good result considering the fact that regression uses only variables related to market characteristics of the recommendations issued, omitting other spheres influencing the occurrence of excessive optimism among analysts.
\end{abstract}

Key words: excessive optimism, stock valuation, capital market, investments, Poland, Warsaw Stock Exchange

JEL classification: $G 02, G 12, G 14, G 17$

\footnotetext{
Received: 22-02-2019; accepted: 25-06-2019

1 Associate Professor., University of Lodz, Faculty of Economics and Sociology, Rewolucji 1905 St. No 39, 90-214 Lodz, Poland. Scientific affiliation: economics. Phone: +48 426354832. E-mail: radoslaw.pastusiak@uni.lodz.pl.

${ }^{2}$ MA, University of Lodz, Faculty of Economics and Sociology, Rewolucji 1905 St. No 39, 90214 Lodz, Poland. Scientific affiliation: economics. Phone: +484263548 32. E-mail: jakub. keller@uni.lodz.pl.
} 


\section{Introduction}

The phenomenon of optimism in finance leads to an unrealistic view of the surrounding economic reality, which often leads to mistakes in decisions. In the case of business valuation, excessive optimism is the cause of the overestimation of the evaluated enterprises. However, the scale of overestimation or underestimation of the valuation resulting from excessive optimism in the collection is heterogeneous, from the point of view of the impact of additional factors. It turns out that such elements as the brokerage house, industry, and market phase also have their significance for the phenomenon of excessive optimism.

The text proposed by the authors refers to the phenomenon of excessive optimism in brokerage valuations, which manifests itself through their valuations of securities in a way that is unilaterally biased against the prices actually achieved. In their deliberations, the authors refer to the study of the same issue on various world stock exchanges, especially to the analysis of Eames, Glover, Kennedy (2002), Clarke, Ferris, Jayaraman, Lee (2006), or Balboa, Gomez-Sala, Lopez- Espinosa (2009).

The phenomenon of excessive optimism is complex from the point of view of the individual characteristics of stock market analysts, as well as the psychological aspects of market functioning and the mechanisms determining the volatility of share prices. Due to the wide range of factors affecting the occurrence of the studied phenomenon, the authors focus only on market aspects affecting the occurrence of excessive optimism in brokerage recommendations. Particular attention was paid to the phase of the market in which the recommendation was issued, the nature of the published report, the industry to which the company and the institution issuing the recommendation should be valued.

The authors focused on assessing the uniformity of the occurrence of the phenomenon of excessive optimism in the segregation of valuations in relation to the adopted variables. According to the researchers, the analyzed phenomenon does not appear on the Polish market to the same extent in all market segments, as well as individual financial institutions conducting market analyzes are not at the same level exposed to distortions of performed analyzes.

Further part of the presented article divided into sections: literature review, research methodology, empirical data and analysis, results and discussion, and conclusions. The authors analyzed key literature on the subject under study, so that they could better understand the research gaps and outline the background of the proposed deliberations. The study presented in the article analyzes over 10,000 recommendations for companies from the Warsaw Stock Exchange and from over 40 financial institutions, in which we value companies in the years 2000-2014. For the needs of analyzes, excessive optimism in valuations was defined as the revaluation of the target price in the case of positive valuation and 
underestimation of the decrease in negative recommendations. Authors, using qualitative variables referring to the parameters included in the study, used logit regression. In order to determine the probability of excessive optimism in a given recommendation. The authors hypothesize that in brokerage recommendations, on the Polish market, there is a phenomenon of excessive optimism, which distorts published valuations, but this phenomenon is not homogenous in all segments and market institutions.

\section{Literature review}

Fundamental to the decisions made are psychological properties of the assessment process by people. It is worth recalling the perspective theory of Kahneman and Tversky (1979) and its main assumption: when assessing whether something is beneficial or not, the decision maker adopts some point of reference. Heuristics are mentioned: anchoring and adaptation, availability and representativeness (Nęcka et al., 2008).

Heuristics of anchoring and adaptation takes place when the assessment and forecast as to the size (reflected numerically) of a given phenomenon are based on a different, sometimes any value. This accidental value becomes an anchor, a reference point, a context for the mental operation important from the perspective of the task being performed. The use of anchoring heuristics and adjustments is responsible for incorrect evaluations and forecasts due to insufficient modification of the initial value. Following the recommendations of other analysts may result not only from the error of anchoring but also from the herd behavior effect or tendency to duplicate the behavior or views of the comparative group.

The reason for issuing erroneous assessments is the overconfidence of the assessor. Zielonka (2014) lists several aspects: the outstanding effect, the effect of calibration, the illusion of control and unjustified optimism. Overconfidence is a tendency to overestimate one's competence and it occurs when the certainty of the judgments given exceeds their accuracy. The process of assessing the value and forecasting changes on the financial markets is susceptible to errors and distortions (Zaleśkiewicz, 2015; Zielonka, 2014). They may be a result of the interaction of situational or psychological factors which ensue from the cognitive limitations of the person.

The phenomenon of excessive optimism has been indicated in some earlier studies. Authors have typically focused on the overestimation of cash flows and target stock prices in relation to the real figures that have been observed in the markets. Those kind of studies were presented by Butler, Lang (1991), Brous, Kini (1993), Francis, Philbrick (1993), Dreman, Berry (1995), Brown (1996), Rajan, Servaes (1997), Brav, Lehavy (2003). Most of those authors see the over optimism problem 
as a result of occurring heuristic biases among the analytics and the financial markets regulations that often promote optimistic predictions and transaction recommendations over the pessimistic ones.

In the context of IPO Dugar, Nathan (1995) focused on the influence of the analyst affiliation on the forecast optimism factor. They concluded that companies that were valued by the analyst connected in some way to the company or the institution responsible for conducting the IPO were more overpriced in the recommendations. Similar conclusions were stated by Dechow, Hutton, Sloan (2000). Other authors, like Branson (1998) or Bradley (2003) denied the differences between the forecasts of these two groups of analysts. It should be noted that the differences that may occur in the forecasts of the affiliated and unaffiliated analytics may also be a result of the different information spectrum available for them. Analysts directly involved in the IPO process may have access to some additional information that would not be available for external analysts and investors.

In the case of stock market recommendations, the phenomenon of excessive optimism manifests itself through revaluation of goodwill, in the case of positive recommendations about it, as well as underestimation of the value of shares in case the analyst values the company lower than the current market price. Eames, Glover, Kennedy (2002) analyzed brokerage profit forecasts and recommendations from 1988-1996. The main element of their research was the verification of the quality of predictions of brokers, reflected in the deviations between the forecasted and the actual size of the EPS index in the surveyed companies, in the horizon of more than one year. Ultimately, the researchers sought to verify the occurrence of excessive optimism heuristics in the prepared studies, which is why the analysis were focused on the correctness and not the usefulness of broker's recommendations. The effect of the work was to say that analysts' forecasts are significantly overstated in the case of buy recommendations, while they are too pessimistic with the "sell" announcements. The obtained results are characterized by statistical significance. A similar research problem was posed by Clarke, Ferris, Jayaraman, Lee (2006), asking questions about the occurrence of excessive optimism in brokerage recommendations, embedded specifically in the situation of filing applications for bankruptcy by valued enterprises. They examined 384 companies that started the bankruptcy proceedings in the period 1995-2001. The research constructed in this way was aimed at firstly verifying the occurrence of heuristics in the process of creating valuations, and secondly assessing the market reaction to the published recommendations. It should be noted that the context chosen by the authors was very strongly marked with negative aspects resulting from the situation of the analyzed companies, therefore, in the case of excessive optimism, these heuristics should be confirmed even more. The results of the conducted research have shown that the reports carried out by analysts are not precise and it is difficult to parameterize errors that arise in them. 
Morgan, Stocken (2003) emphasized that the market provisions that analyst gain from investors transactions may also be the factor encouraging them to show more optimistic recommendations suggesting to buy stocks. Constantinou, Forbes, Skerratt (2003) confirmed the optimism bias among analytics showing that they tend to be underreacting for the negative information for the valued companies. Toshino, Suto (2004) studied the forecasts made by Japanese financial institutions. Their research resulted in showing that many different heuristics occur among those companies. They claimed that institutional investors in Japan tend to make longer forecasts that are biased by optimism, heuristics of availability and over optimism. Azzi, Bird, Ghiringhelli, Rossi (2005) conducted similar studies in Europe and they came to same conclusions. Recommendations issued in most of the countries were mostly effective in prosperity periods and chaotic in transaction signaling when the markets were in the bear phase. This is also a result of the fact that analysts tend to issue buy recommendations with same frequency in every market phase.

Lyra (2009) studied heuristics influence on the markets indirectly, by showing that the algorithm investment strategies are more effective in portfolio management due to the fact that without them, investment process is affected by lot of biases. Similar approach was presented by Gilli, Schumann (2012). They assumed that the heuristics are decreasing portfolios efficiency and proposed alternative, algorithmbased strategy that was more effective. Their study shown the significant role of heuristics in markets functioning.

Balboa, Gomez-Sala, Lopez-Espinosa (2009), performing a global analysis of this phenomenon, showed that it is the strongest among American and British analysts, while the phenomenon of excessive optimism is also important among specialists from other countries. Also in the context of heuristic errors occurring on the analysts' side, it is necessary to pay attention to the possibility of conformism and herd behavior when executing recommendations. Research on this topic was presented by Jegadeesh, Kim (2010). In their work, they probed thoroughly studies from 1996-2005 and on their basis, they managed to show that stud behaviors are present among analysts. This, on the other hand, may lead to the conclusion that the emergence of a valuation of a given nature will increase the chance that other institutions that plan to issue recommendations in a similar time will issue a judgment of similar nature to the original recommendation, especially if it comes from a serious source ${ }^{3}$.

Undoubtedly, the phenomenon of the occurrence of excessive optimism on a mass scale, which manifests itself by dominating the market through optimistic valuations, is complex and its foundations are to be found on many levels. It is

\footnotetext{
3 The occurrence of such behavior patterns is strengthened by the so-called "guru effect" and "anchoring effect", which increase the probability of the institutions following the recognized leader and referring in their assessments to those included in the previously presented reports.
} 
undisputed, that it is a fact observed on the Warsaw Stock Exchange, just like on other dance floors surveyed in this respect. The literature presented above is mainly focused on detecting the occurrence of the over optimism bias on the markets but in authors perspective, these phenomena can be studied further to develop procedures helping to reduce the impact of over optimism on target prices in stock recommendations. In this article we presented our perspective on the distribution of the heuristic in the polish stock market in reference to some variables describing the sell-side recommendation reports. The presented procedure would help to identify the market segments that are most and the least exposed for the over optimism influence. Results of the study should help to understand the nonlinear character of the studied phenomena and would be a base for further analysis targeted on quantifying the over optimism in particular segments.

\section{Methodology}

In order to verify the hypothesis, sell-side recommendations were issued, issued by Polish and foreign brokerage houses, for companies listed on the main market of the Warsaw Stock Exchange. In order to achieve the set goals, each of the recommendations included in the analysis had to contain information about:

1. Recommended company

2. The institution preparing the valuation

3. Date of issue of the recommendation

4. Message with transaction recommendation

5. Prices of the target share

The list of published stock market recommendations in the assumed research period was obtained via industry websites (bankier.pl, StockWatch.pl, GPWinfostrefa) and direct websites of brokerage houses, which published their recommendations free of charge. However, it should be noted that brokerage houses publish their recommendations on the general site, in a selective manner and indicating the willingness to present only studies of historically highest verifiability. This type of measurement is aimed at presenting a brokerage house product, which is undoubtedly a recommendation, as a maximally reliable and encouraging transaction for the investor, which translates into the profits of the brokerage house charging commissions on concluded transactions. The considerations presented in this article also refer to the aspect of issuing recommendations in a specific market phase, once the interest of brokerage houses and investors in a given company, which in the study is illustrated by the number of recommendations issued for a given company (interest of brokers) and the average number of transactions performed on a given company the company (interest of investors). 
The analysis period is between January 2010 and December 2014. Referring to several basic theories of fluctuations in business and stock exchange cycles, it should be noted that assuming the Kitchin cycle lasts an average of 3.5 years, the analysis period covers less than 6 full cycles of the business cycle. Also for Juglar cycles lasting 8 to 10 years. Research conducted directly on the Polish market, made by Z. Wośko (2006), indicates that the economic cycle in Polish conditions lasts about 52.7 months, while the full stock exchange cycle is about 31.2 months. This means that the adopted research period exceeded 2.2 times the economic cycle and over 3.8 times the stock exchange. In the light of the above, it should be noted that the adopted research period allows analyzing the examined phenomenon in each phase of the business cycle and the stock exchange cycle.

Growth potential $\left(P W_{i}\right)$ - This is the potential level of change in the value of shares resulting from the difference between the target price indicated in the recommendation and the opening price of the given asset at the session on the day the recommendation was published.

$$
P W_{i}=\frac{P_{t}-P_{0}}{P_{0}}
$$

Trend $\left(T_{i}\right)$ - This variable refers to the current (for a given recommendation) development trend of the entire market represented by the WIG index. Introduction of this parameter will allow verifying the impact of the current market trend on the effectiveness of the recommendation's impact on prices in accordance with their overtones,

Number of recommendations $\left(I R_{i}\right)$ - illustrates the number of recommendations issued for a given company participating in the study (over 340 entities were included in the study),

Number of transactions $\left(I T_{i}\right)$ - illustrates the average number of transactions performed on a given company on 1 trading session,

Type of recommendation [Sell (T1), Reduce (T2), Neutral (T3), Accumulate (T4), Buy (T5)] - Variables showing the meaning of a given brokerage recommendation. According to the perspective theory of Kahnemann, Tversky (1979), positive and negative messages are received in a different way, while those encouraging the sale of shares in accordance with the utility function should trigger stronger feelings and reactions of investors.

Brokerage $\left(D M 1_{i}, D M 50_{i}\right)$ - Parameters concerning brokerage houses participating in the survey constitute a set of fifty binary variables related to evaluating institutions. Each recorded record in the created research sample is assigned one binary variable of the brokerage house with the value of 1 , with the remaining 49 with the value of 0 . 
Industry $\left(B R_{1}, B R_{28}\right)$ - Variables related to the industry were established in the same way as in the case of brokerage houses, that is, they define the main sector of activity of a given enterprise through the privatization of one of the 28 binary variables reflecting the industry included in the study.

The study uses the logit model, which is based on the proper determination of the explained zero-one variable adequate to the assumed goal and hypothesis. In the case of the considerations, the variable illustrating the occurrence of excessive optimism was determined as follows:

For positive recommendations:

$y_{i}=\left\{\begin{array}{l}1, \text { if (recommended price-price after a year of recommendation })<0 \\ 0, \text { if }(\text { recommended price-price after a year of recommendation })>0\end{array}\right.$

For negative recommendations:

$y_{i}=\left\{\begin{array}{l}1, \text { if }(\text { recommended price-price after a year of recommendation })>0 \\ 0, \text { if }(\text { recommended price-price after a year of recommendation })<0\end{array}\right.$

It means that the phenomenon desirable in the conducted research is to capture forecasts overestimating prices in positive and underestimating recommendations in negative recommendations, in order to later determine the determinants of such situations. The logit model used in the study is based on the logistic function expressed in the formula:

$$
y_{i}=\frac{\alpha}{1+\beta e^{-\gamma i}}+\varepsilon_{t} \quad \text { where } \alpha>0, \beta>1, \gamma>0
$$

The logistic function can also be saved in a different version, in which the saturation value equal to 1 is assumed, allowing for modeling the probability of occurrence of a specific phenomenon. Then the function can also be defined as:

$$
y_{i}=\frac{e^{Z_{i}}}{1+e^{Z_{i}}}
$$

Hence the probability model has the form:

$$
p_{i}=\frac{e^{Z_{i}}}{1+e^{Z_{i}}}
$$

Where $Z_{i}$ is a function based on explanatory variables shaping the probability tested.

$$
Z_{i}=\beta_{0}+\beta_{1} * X_{1}+\beta_{2} * X_{2}+\ldots+\beta_{k} * X_{k i}+\varepsilon_{i}
$$


Where the $\beta_{i}$ coefficients result from the estimation of the model form, the $X_{i}$ parameters are variables used as determinants of the probability of occurrence of the examined event, while $\varepsilon_{i}$ is the random component of the model.

Ultimately, you can, therefore, save that the tested model has the general form (8):

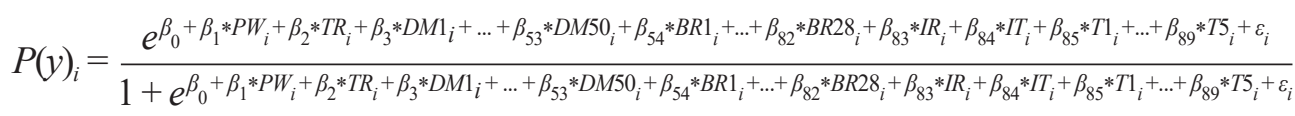

The created models will also be evaluated in terms of their matching measure. For this purpose, the coefficient $R^{2} M c F a d d e n a$ and the count $R^{2}$ were used.

$$
R^{2} \text { McFadden }=1-\frac{\log \left(L_{U R}\right)}{\log \left(L_{R}\right)}
$$

Where:

$L_{U R}-$ Means the maximum reliability function if we maximize it in relation to all parameters,

$L_{R}$ - Means maximum when maximized with a condition $\beta_{i}=0$, where $\mathrm{i}=1,2, \ldots, \mathrm{k}$

We can say, then, that the McFadden measure describes the ratio of the finally determined model to the regression containing only the free word. We can use it to assess the size of the combined effect of specific variables on the studied phenomenon.

The second measure is the so-called $R^{2}$ counting, based on the proportion of accurate forecasts. Because the explained variable assumes a value of 1 in the case when the calculated probability from the model for the ith observation is higher than 0.5 and 0 for the opposite situation. Then we can also write that:

$$
R^{2} \text { counting }=\frac{\text { number of accurate forecasts }}{\text { total number of observations }}
$$

\section{Empirical data and analysis}

The performed estimation led to the reduction of the input model which contained 89 variables to the form presented in the table below. Despite the truncated form of the function, it still contains variables that refer to all types of parameters analyzed in the presented study. 
Radostaw Pastusiak, Jakub Keller • Determinants of occurrence of excessive optimism...

Table 1: Logit estimation of the occurrence of optimism in valuations

\begin{tabular}{|c|c|c|c|c|c|}
\hline Variable & Coefficient & Standard error & $\mathrm{z}$ & Value $p$ & \\
\hline const & 2.23932 & 0.0887894 & 25.2206 & $<0.00001$ & $* * *$ \\
\hline Trend & -1.37224 & 0.0508589 & -26.9814 & $<0.00001$ & $* * *$ \\
\hline IT & 0.000128695 & $5.60015 \mathrm{e}-05$ & 2.2981 & 0.02156 & $* *$ \\
\hline IR & -0.0019186 & 0.000252678 & -7.5931 & $<0.00001$ & $* * *$ \\
\hline sell & -1.41439 & 0.0806337 & -17.5410 & $<0.00001$ & $* * *$ \\
\hline reduce & -1.22576 & 0.0878452 & -13.9537 & $<0.00001$ & $* * *$ \\
\hline accumulate & -0.541611 & 0.0518762 & -10.4404 & $<0.00001$ & $* * *$ \\
\hline Finance & 0.511198 & 0.288531 & 1.7717 & 0.07644 & $*$ \\
\hline Developer & 0.469298 & 0.12918 & 3.6329 & 0.00028 & $* * *$ \\
\hline Media & 0.39811 & 0.108328 & 3.6751 & 0.00024 & $* * *$ \\
\hline Gross sales & -0.314697 & 0.112996 & -2.7850 & 0.00535 & $* * *$ \\
\hline Information technology & 0.436639 & 0.0964645 & 4.5264 & $<0.00001$ & $* * *$ \\
\hline Architecture & 0.313828 & 0.099618 & 3.1503 & 0.00163 & $* * *$ \\
\hline Automotive industry & 0.442589 & 0.233714 & 1.8937 & 0.05826 & $*$ \\
\hline Retail & -0.726515 & 0.110443 & -6.5782 & $<0.00001$ & $* * *$ \\
\hline Banking & -0.598731 & 0.0876396 & -6.8317 & $<0.00001$ & $* * *$ \\
\hline Services & 1.22373 & 0.393459 & 3.1102 & 0.00187 & $* * *$ \\
\hline Chemical industry & -0.660032 & 0.113476 & -5.8165 & $<0.00001$ & $* * *$ \\
\hline Energetics & 0.95307 & 0.160974 & 5.9206 & $<0.00001$ & $* * *$ \\
\hline Pharmaceutical industry & 1.27866 & 0.40743 & 3.1384 & 0.00170 & $* * *$ \\
\hline Resources & 0.246019 & 0.12664 & 1.9427 & 0.05206 & $*$ \\
\hline Oil industry & 0.341973 & 0.110895 & 3.0837 & 0.00204 & $* * *$ \\
\hline Telecommunication & 0.905453 & 0.12646 & 7.1600 & $<0.00001$ & $* * *$ \\
\hline Trigon & -1.52041 & 0.429396 & -3.5408 & 0.00040 & $* * *$ \\
\hline BZWBK & -0.236926 & 0.0935864 & -2.5316 & 0.01135 & $* *$ \\
\hline Amer Brokers & -0.401366 & 0.214059 & -1.8750 & 0.06079 & $*$ \\
\hline ING Securities & -0.358248 & 0.122403 & -2.9268 & 0.00342 & $* * *$ \\
\hline mBank & -0.158429 & 0.0709592 & -2.2327 & 0.02557 & $* *$ \\
\hline Millennium & -0.355931 & 0.0943164 & -3.7738 & 0.00016 & $* * *$ \\
\hline PKOBP & -0.429731 & 0.105631 & -4.0682 & 0.00005 & $* * *$ \\
\hline Uni Credit & -0.64289 & 0.0920117 & -6.9871 & $<0.00001$ & $* * *$ \\
\hline KBCS & -0.298479 & 0.0926279 & -3.2223 & 0.00127 & $* * *$ \\
\hline BDM & -0.394222 & 0.171283 & -2.3016 & 0.02136 & $* *$ \\
\hline $\mathrm{BPH}$ & -0.614761 & 0.187295 & -3.2823 & 0.00103 & $* * *$ \\
\hline Deutsche Bank & -0.416451 & 0.133949 & -3.1090 & 0.00188 & $* * *$ \\
\hline PEKAO & -0.631075 & 0.127922 & -4.9333 & $<0.00001$ & $* * *$ \\
\hline BOŚ & -0.662076 & 0.10211 & -6.4839 & $<0.00001$ & $* * *$ \\
\hline Espirito Santo & 0.505084 & 0.238293 & 2.1196 & 0.03404 & $* *$ \\
\hline UBS & -0.374626 & 0.225138 & -1.6640 & 0.09611 & $*$ \\
\hline Credit Suisse & 0.574317 & 0.251736 & 2.2814 & 0.02252 & $* *$ \\
\hline JP Morgan & 0.929574 & 0.324253 & 2.8668 & 0.00415 & $* * *$ \\
\hline Cheuvreux & 1.58812 & 0.849564 & 1.8693 & 0.06158 & $*$ \\
\hline
\end{tabular}

Source: own study (10591 observations) 
At the beginning the variable "TR" illustrating the current market trend should be noted. As predicted, this parameter is important from the point of view of revaluation in valuations of brokers. The beta factor indicates that recommendations issued in accordance with the current trend have a lower chance of overestimating the target values. Analyzing the extreme effect of this variable, we can see that it reduces the probability of excessive optimism by over $31 \%$.

The next parameters refer to the popularity of the examined entity. The fact that the company is often measured by brokerage houses (IR), according to the above model reduces the likelihood of the revaluation of the company by analysts. It should be noted, however, that this variable, despite statistical significance, has a very small influence on the phenomenon studied. While maintaining invariable the remaining parameters of the model, the execution of each successive recommendation reduces the chances of an excessive optimism about $0.0470 \%$. While increasing the trade interests of the company reflected by the number of transactions increases the chance of getting the market value lower than expected in the recommendations. Increasing the average number of transactions per session by one unit increases the probability of occurrence of the studied phenomenon by $0.0032 \%$. According to the authors, this is due to the fact that investors are watching target prices contained in the recommendations and, if the price of the advantages of coming to the predicted values, they begin to transact more cautious in terms of generating further demand that could lead to an increase in prices above the recommended (or supply in the case of negative recommendations).

An important group of variables influencing the studied phenomenon is those referring to the type of message convicted in the recommendation. This means that reports on positive and negative overtones give a different chance of occurrence of excessive optimism in the valuation of a given company. According to the specification of the model, statistical significance was not obtained for the variables "buy" and "neutral", which means that in these two groups of recommendations the conclusions are ambiguous. However, the other three types of valuations were included in the model. Each of them points to a decrease in the probability of excessive optimism in case the recommendation is marked with a message belonging to these three categories. In the case of sales recommendations, the probability of excessive optimism is reduced by over $33 \%$, in the group "reduce" the chance is reduced by over $29 \%$, while in the group accumulate by " $13 \%$ ". It is easy to notice that negative reports reduce the chance of excessive optimism in the annual horizon. This, in turn, means that investors receiving a recommendation with such a message are more likely to make transactions that result in a price reduction to the projected values. This coincides with the conclusions described by Kahneman (1979), telling me that negative information determines our actions more strongly.

The next group of variables studied refers to individual brokerage houses publishing stock exchange recommendations. The authors noted that both world literature 
and research for the Polish market point to the distinction of the acceptance of recommendations from institutions of varying reputation, which translates into market behavior and price changes in the case of a report coming from individual and different institutions. The phenomenon of excessive optimism also applies to the corporate culture of each Brokerage House and the valuation rules prevailing in it, as well as the Rules for creating recommendations. Different methods of analysis, tools, and experience of individual analysts influence the possibility of excessive optimism occurring in various areas in individual institutions. The thesis of this confirmation obtained results, derived from the obtained econometric model.

Recommendations from different brokerage houses determine, to varying degrees, the chance of overestimating forecasted increases or underestimating declines. In the case of most brokerage houses for which statistical significance was obtained in the analysis, the reports published by them are less likely to re-evaluate the surveyed entities, although, in the case of institutions such as JP Morgan, there is an over $20 \%$ increased likelihood of excessive optimism. On the other hand, valuations from UniCredit reduce the probability of occurrence of the examined phenomenon by almost $16 \%$. Being aware of such discrepancies, an investor using brokerage recommendations, using the conclusions from the presented model, can assess whether the target price declared by the institution has a chance to exist in the actual market quotations or should be reduced/increased due to historical statistical verifiability of valuations data of brokerage houses.

The last group of parameters examined refers to the issue of the occurrence of optimism in particular market segments. Due to the different perspectives and the nature of the functioning of individual industries, according to the authors, the possibility of making stable and precise valuations by brokerage houses varies from sector to sector. This, in turn, results in a different risk distribution of the results of appropriately evaluated or underestimated results, depending on the industry studied. As in the case of analyzes of individual institutions, in the course of determining the final form of the model, many of the surveyed industries were found to be inconclusive, which makes it impossible to conclude unambiguously about them. However, it was possible to select a group of sectors in which the examined phenomenon is more explicit. According to the model, the highest probability of excessive optimism is associated with the pharmaceutical industry (25.6\%) and the service industry $(24.8 \%)$. In contrast, potentially underestimated valuations are most often observed in the chemical industry (probability -16.4\%) and in retail trade, which reduces the probability of occurrence of the studied phenomenon by almost $18 \%$. As in the case of applications from individual financial institutions, an investor analyzing recommendations for given companies, knowing the sector of their operations, is able to use the above model to determine the precision of forecasts issued in the recommendation and the direction of possible reduction, consistent with the conclusions from the model. 
The proposed formula refers to a specific and specific set of technical parameters defining stock exchange recommendations, which may determine the probability of the phenomenon of excessive optimism. These parameters allow a more precise way to determine niches of the market, in which the studied phenomenon is a significant heuristic problem. The proposed function does not capture very many specific features concerning the analysts themselves, as well as omits, for example, aspects related to the shape of the transaction system operating on a given exchange. This means that further research may expand the set of variables included in the analysis with further parameters that may broaden the conclusions about the studied phenomenon. Nevertheless, the proposed function allowed for the correct prediction of excessive optimism in almost $70 \%$ of the cases of publication of the exchange recommendations included in the study.

Table 2: Basic parameters describing the predictive effectiveness of the model

\begin{tabular}{|c|c|c|c|}
\hline $\begin{array}{c}\text { The arithmetic mean of the } \\
\text { dependent variable }\end{array}$ & 0.557077 & $\begin{array}{c}\text { the standard deviation of a } \\
\text { dependent variable }\end{array}$ & 0.496755 \\
\hline McFadden $\mathrm{R}^{2}$ & 0.144155 & Adjusted $\mathrm{R}^{2}$ & 0.138379 \\
\hline \multicolumn{4}{|c|}{ Number of 'correct prediction' cases $=7302(68,9 \%)$} \\
\hline
\end{tabular}

Source: own study

According to the authors, the obtained result of correct predictions is satisfying considering the limited number of variables included in the analysis. Interesting and important are also the conclusions from individual variables, especially in the context of stock exchange transactions using brokerage recommendations. It should be noted, however, that the form of the model was determined strictly based on the observations for the Polish market, which significantly hampers the translation of their results into other stock markets. It should be noted, however, that the Warsaw Stock Exchange is an important market in this part of the world and is an attractive place to carry out investments, which makes such analyzes important from the point of view of better understanding of market mechanisms and improving the efficiency of capital allocation on the stock exchange. In addition, the proposed task in the context of the presented variables and the method of analysis in a relatively easy way allows translating the conducted conclusions on other floors in the world.

\section{Results and discussion}

The aim of the presented article was to investigate the occurrence of the phenomenon of excessive optimism on the WSE and an attempt to assess the uniformity of its distribution in various market segments. Results from the carried study fit into the research trend showing how heuristics are important factor 
affecting the stock market. Also the conducted model show that the analyzed phenomena is very different in particular market segments divided by the variables used in the study. In authors point of view, knowledge about the chance that the received recommendation is affected by the over-optimism heuristic with a certain probability is enriching the decision making process even though the degree of "error" in the target price is not defined on this research stage. Authors plan to carry on further analysis targeted on calculating the estimated optimism factor that could be used to modify the initial target prices in stock recommendations. This process assumes the necessity of analysis more groups of variables referring to: company situation at the time of issuing the recommendation, state of the market at that time and also some characteristics of the analyst preparing the report itself.

At this stage authors would like to identify the market segments and institutions that are affected the least and the most by overoptimistic forecasts and recommendations as this would be a foundation to further study in finding the differentiates between them. Authors are interested in creating the models showing the probability and the degree of overoptimistic forecast in reference to a set of variables describing the institution issuing the recommendations, the valued company and the state of the market at the time of the valuation. That process would help to improve the objectivism of the investment process that would lead to better and more efficient capital allocation.

\section{Conclusions}

The obtained results confirmed the researchers' assumptions about the inhomogeneity of the occurrence of excessive optimism both in relation to various economic sectors and individual financial institutions. The model created by the authors effectively predicted the occurrence of excessive optimism in the valuation of brokers in $70.1 \%$ of the cases studied. The authors consider this to be a good result considering the fact that regression uses only variables referring to market characteristics of issued recommendations, omitting other spheres affecting the occurrence of excessive optimism among analysts.

Referring to the model, the recommendations that are most likely biased by the overoptimism in target prices are those stated by JP Morgan and Credit Suisse for companies in telecommunication, energetics and IT sectors. On the other hand, the reports that are the least likely to by overoptimistic are those issued by PKO BP, PEKAO and BOŚ Bank for companies functioning in retail, chemistry and banking sector. The probability of occurrence of overoptimism in those two opposed groups of reports can reach tens of percent and that should be considered a significant difference. Also the proposed model shows how different types of recommendations can differ in this aspect. Considering the studied factors authors came to the 
conclusion that the phenomena of overoptimism cannot be analyzed further in the global group of recommendations. The reports should be firstly divided into smaller groups with their own characteristics in terms of studied heuristic and then each group should be examined separately.

The analysis carried out significantly contribute to expanding knowledge about investments on the Polish stock market and behavioral aspects of the functioning of financial markets. The presented research is also unique due to the lack of a similar development for the Polish market, which was made on such a long time trial and with the use of the proposed variables. For this reason, a direct comparison of the results obtained with similar surveys for the Polish market is not possible. The presented method of analyzing the discussed issue is not widely recognized in the literature, because the majority of research carried out in this area is descriptive, or case study. This is a reason for quantitative considerations in the scope of excessive optimism, because it is a factor that significantly distorts the valuation process of enterprises and secondarily - the process of capital allocation on the stock market.

\section{References}

Azzi, S. et al. (2005) "Biases and information in analysts' recommendations: The European experience", Journal of Asset Management, Vol. 6, No. 5, pp. 345380, doi: 10.1057/palgrave.jam.2240187 2019.04.02.

Balboa, M., Gomez-Sala, J., Lopez-Espinosa, G. (2009) "The Value of Adjusting the Bias in Recommendations: International Evidence", European Financial Management, Vol. 15, No. 1, pp. 208-230, doi: 10.1111/j.1468-036X.2007.00421.x 2019.04.02.

Bradley, D., Jordan, B., Ritter, J. (2003) "The quiet period goes out with a bang", Journal of Finance, Vol. 58, pp. 1-36, doi: 10.1111/1540-6261.00517 2019.04.02.

Branson, B., Guffey, D., Pagach, D. (1998) "Information conveyed in announcements of analyst coverage", Contemporary Accounting Research, Vol. 15, pp. 119-143, doi: 10.1111/j.1911-3846.1998.tb00552.x 2019.04.02.

Brav, A., Lehavy, R. (2003) “An empirical analysis of analysts' target prices: short term informativeness and long term dynamics", Journal of Finance, Vol. 58, pp. 1933-1968, doi: 10.2139/ssrn.266180 2019.04.02.

Brous, P., Kini, O. (1993) "A reexamination of analysts earnings forecasts for takeover targets", Journal of Financial Economics, Vol. 33, pp. 201-226, doi: 10.1016/0304-405X(93)90004-U 2019.04.02.

Brown, L. (1996) "Analyst forecasting errors and their implications for security analysis: an alternative perspective", Financial Analyst Journal, Vol. 52, pp. 40-47, doi: 10.2469/faj.v52.n1.1965 2019.04.02. 
Butler, K., Lang, L. (1991) "The forecast accuracy of individual analysts: evidence of systematic optimism and pessimism", Journal of Accounting Research, Vol. 29, pp. 150-156, doi: 10.1177/0148558X0301800412 2019.04.02.

Clarke, J. et al. (2006) "Are Analyst Recommendations Biased? Evidence from Corporate Bankruptcies", Journal of Financial and Quantitative Analysis, Vol. 41, No. 1, pp. 169-196, doi: 10.1017/S0022109000002465 2019.04.02.

Constantinou, C., Forbes, W., Skerratt, L. (2003) Analyst Underreaction in the United Kingdom, Financial Management, Vol. 32, No. 2, 93-106, doi: 10.2307/3666338 2019.04.02.

Dechow, P., Hutton, A., Sloan, R. (2000) "The relation between analysts' forecasts of long-term earnings growth and stock price performance following equity offerings", Contemporary Accounting Research, Vol. 17, pp. 1-32.

Dreman, D., Berry, M. (1995) "Analyst forecasting errors and their implications for security analysis", Financial Analysts Journal, Vol. 51, pp. 30-41, doi: 10.2469/ faj.v51.n3.1903 2019.04.02.

Dugar, A., Nathan, S. (1995) "The effect of investment banking relationships on financial analyst's earnings forecasts and investment recommendations", Contemporary Accounting Research, Vol. 12, pp. 131-160.

Eames, M., Glover, S.M., Kennedy, J. (2002) "The Association between Trading Recommendations and Broker-Analysts' Earnings Forecasts", Journal of Accounting Research, Vol. 40, pp. 85-104. doi: https://www.jstor.org/stable/3542431.

Francis, J., Philbrick, D. (1993) “Analysts' decisions as products of a multi-task environment", Journal of Accounting Research, Vol. 31, pp. 216-230, doi: 10.2307/2491271 2019.04.02.

Jegadeesh, N., Kim, W. (2010) "Do Analysts Herd? An Analysis of Recommendations and Market Reactions", The Review of Financial Studies, Vol. 23, No. 2, pp. 901-937, doi: 10.3386/w12866 2019.04.02.

Kahneman, D., Tversky, A. (1979) "Prospect theory: An analysis of decision under risk", Econometrica, Vol. 47, pp. 263-292, doi: 10.2307/1914185 2019.04.02.

Lyra, M. (2010) "Heuristic Strategies in Finance - An Overview", COMISEF Working Papers Series WPS-045 21/09/2010.

Morgan, J., Stocken, P. (2003) "An Analysis of Stock Recommendations", The RAND Journal of Economics, Vol. 34, No. 1, 183-203, doi: 10.2307/3087449 2019.04.02.

Rajan, R., Servaes, H. (1997) "Analyst following of initial public offerings", Journal of Finance, Vol. 52, pp. 507-529, doi: 10.1111/j.1540-6261.1997.tb04811.x 2019.04.02.

Toshino, M., Suto, M. (2004) "Cognitive Biases of Japanese Institutional Investors: Consistency with Behavioral Finance", 12th Conference on the Theories and Practices of Securities and Financial Markets, National Sun Yat-sen University, Kaohsiung, Taiwan. 
Wośko, Z. (2006) Wpływ zmian na rynkach finansowych na przebieg wahań koniunkturalnych w Polsce, Ph.D. thesis.

Zielonka, P., (2014) Gietda i psychologia. Behawioralne aspekty inwestowania na rynku papierów wartościowych, $\mathrm{CeDeWu}$, Warszawa.

\title{
Odrednice pojave pretjeranog optimizma među analitičarima Varšavske burze
}

\author{
Radostaw Pastusiak ${ }^{1}, J_{a k u b}$ Keller $^{2}$
}

\begin{abstract}
Sažetak
U ovom se radu obrađuje fenomen pretjeranog optimizma $u$ brokerskim procjenama, što se očituje u jednostranim pogreškama u vrednovanju vrijednosnih papira u odnosu na realnu cijenu koju pojedine dionice ostvaruju u okviru jedne godine. Fenomen pretjeranog optimizma složen je kako iz perspektive individualnih karakteristika burzovnih analitičara, tako i iz psiholoških aspekata funkcioniranja tržišta i mehanizama koji određuju volatilnost cijena dionica. S obzirom na široki raspon čimbenika koji utječu na pojavu istraživane pojave, autori se usredotočuju samo na tržišne aspekte koji utječu na pojavu pretjeranog optimizma u brokerskim preporukama. Istraživanje ispituje više od 10.000 preporuka za tvrtke s Varšavske burze $i$ više od 40 financijskih institucija koje su ocijenile tvrtke u razdoblju od 2000. do 2014. godine. Za potrebe analize, pretjerani optimizam u vrednovanju definira se kao precjenjivanje ciljne cijene u slučaju pozitivnih preporuka i kao podcjenjivanje pada cijena u slučaju negativnih. Rezultati su potvrdili hipoteze o heterogenosti fenomena prekomjernog optimizma kako za različite gospodarske sektore tako i za pojedine financijske institucije. Autori to vide kao dobar rezultat s obzirom na to da regresija koristi samo varijable vezane uz tržišne karakteristike izdanih preporuka, izostavljajući druge sfere koje utječu na pojavu pretjeranog optimizma među analitičarima.
\end{abstract}

Ključne riječi: pretjerani optimizam, vrednovanje dionica, tržište kapitala, investicije, Poljska, Varšavska burza

JEL klasifikacija: G02, G12, G14, G17

${ }^{1}$ Izvanredni profesor. University of Lodz, Faculty of Economics and Sociology, Rewolucji 1905 St. No 39, 90-214 Lodz, Poljska. Znanstveni interes: ekonomija. Tel.: +48 426354832. E-mail: radoslaw.pastusiak@uni.lodz.pl.

2 Magistar ekonomije. University of Lodz, Faculty of Economics and Sociology, Rewolucji 1905 St. No 39, 90-214 Lodz, Poljska. Znanstveni interes: ekonomija. Tel.: +48 426354832. E-mail: jakub.keller@uni.lodz.pl. 
